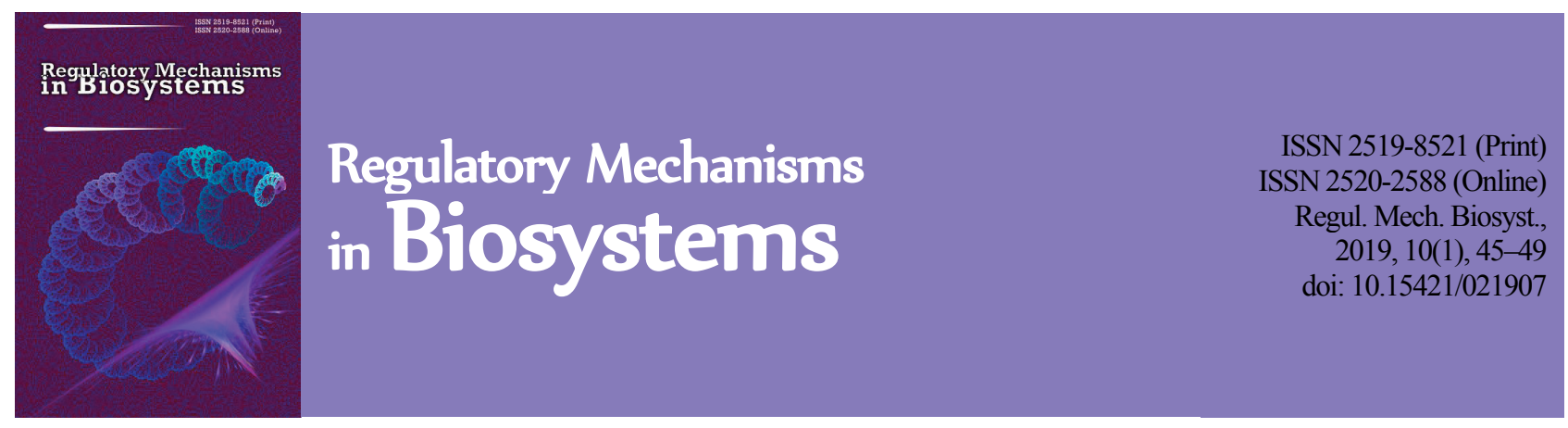

\title{
Analysis of the genetic structure of a population of Lebedyn cattle by microsatellite markers
}

\author{
V. I. Ladyka*, L. M. Khmelnychyi*, Y. V. Lyashenko**, R. O. Kulibaba** \\ *Sumy National Agrarian University, Sumy, Ukraine \\ **Institute of Animal Science of the National Academy of Agrarian Sciences of Ukraine, Kharkiv, Ukraine
}

Article info

Received 09.01.2019

Received in revised form 17.02.2019

Accepted 23.02.2019

Sumy National Agrarian

University, Gerasima

Kondrat'eva st., 160

Sumy, 40021, Ukraine.

Tel.: +38-054-262-78-16.

Institute of Animal Science

of the National Academy

of Agrarian Sciences of

Ukraine, Tvarynnykiv st., $1 A$,

Kharkiv, 61026, Ukraine.

$\mathrm{Tel} \cdot \mathbf{+}+38-057-740-31-81$

E-mail:

tanya_goncharova@meta.ua

\author{
Ladyka, V. I., Khmelnychyi, L. M., Lyashenko, Y. V., \& Kulibaba, R. O. (2019). Analysis of the genetic structure of a population \\ of Lebedyn cattle by microsatellite markers. Regulatory Mechanisms in Biosystems, 10(1), 45-49. doi:10.15421/021907
}

Microsatellites - a separate class of molecular genetic markers, are widely used for the study of genetic variability, in particular in populations of animals bred by artificial selection under the influence of microevolutionary processes. The object of study is the gene pool of a population of animals of the Lebedyn cattle breed, which is under threat of extinction. The sample comprised 30 individuals from the farm "Komyshans'ke" in Sumy region. The analysis of population genetic structure was performed using 10 microsatellite loci recommended by FAO-ISAG: ETH225, BM2113, ETH3, BM1818, BM1824, ILSTS006, INRA023, TAGLA053, TAGLA12, ETH10. Amplification products were separated in polyacrylamide gels of different concentrations (5-8\%), both native and denaturing. All studied loci were polymorphic. The number of detected alleles per locus ranged from 4 to 8 (on average 5 alleles per locus), the size of which ranged from $115 \mathrm{bp}$ (ETH3) to $307 \mathrm{bp}$ (ILSTS006). The majority of the investigated loci (except ETH3) belonged to valuable informative markers (PIC >0.5). The most polymorphic TGLA053 (8 alleles), BM2113 (6) and ETH3 (6) loci have been identified. In general, the minimum number of alleles (4) was fixed in 50\% loci. The main population genetic parameters for the studied loci have been calculated. The highest values of heterozygosity (He), and effective number of alleles (ne) was characterized for loci BM2113, ILSTS006, TGLA053 and ETH225. With the exception of ETH3 and VM1818 loci, the experimental group of animals is in a state of genetic equilibrium. The average value of the Wright fixation index indicates a tendency to increase in the number of homozygous individuals (inbreeding). Comparative analysis of genetic structure of breeds that have a common origin (Lebedyn (PJSC "Mykhaylivka"), Ukrainian grey (DPDG "Polyvanivka"), Red steppe (DPPR "Stepne"), etc.) has been carried out. The obtained results give grounds to assert that in the experimental population of the Lebedyn breed there are processes that lead to a decrease in genetic diversity. In order to overcome the negative effects of artificial reproduction in the gene pool of small populations of cattle, which include Lebedyn cattle, it is appropriate to use microsatellite markers in the selection and breeding work.

Keywords: polymorphism; microsatellites; genotyping; Lebedyn breed; gene pool.

\section{Introduction}

A characteristic feature of the development of dairy cattle breeding in Sumy region in comparison with other regions of Ukraine is the traditional breeding of brown cattle. At the end of the 1970's and early 80 's, the dominant position in Sumy region was occupied by the Lebedyn breed, that has been bred by reproductive crossbreeding of local breeds of cattle (mostly Ukrainian grey) with sires of Swiss breed, followed by breeding (from second or third generation) of the best hybrids "in itself" while improving the conditions of feeding and keeping animals. Creation of the Lebedyn breed was completed and approved in 1950. It became the first domestic breed of brown cattle which was bred in Ukraine (Yatsenko, 1997; Bayda, 1979).

However, against the background of positive indicators that characterize the quality of milk, and the exterior-constitutional type and productive longevity of animals, the Lebedyn breed was not competitive in the conditions of intensification of dairy cattle breeding and industrial production technology, which required a radical improvement of breeding qualities of breeds, especially in the direction of technology of udder and high yield milk production (Sirats'kyy et al., 2001). The consequence of this was the widespread introduction of the highly specialized Holstein breed, which is characterized by the world's highest milk production, excellent exterior type and adaptability to the technological conditions of maintenance and milking (Prokhorenko, 2013). Currently, the Lebedyn breed is listed in the gene pool of endangered breeds despite its unique (as for aboriginal breeds) genetic qualities: excellent adaptation to local conditions of feeding and maintenance, high viability, long-term use, selection flexibility, versatile performance, and, under well established conditions, quite high indicators of dairy type, disease resistance, exterior-constitutional strength and other valuable biological features that are missing in specialized animal breeds (Hladiy et al., 2018; Baranovs'kyy, 2013; Sirats'kyy et al., 2001).

That is, a few local breeds remain carriers of valuable hereditary traits and allelic complexes, without which the further pedigree process would be one-sided. However, these breeds cannot compete with commercial specialized breeds in terms of most of the productivity traits that determine their economic advantage. Consequently, there is a sharp reduction in the number of livestock and the network of breeding farms for this breed. There is an acute problem of preservation of the gene pool of local breeds of animals with limited populations, the disappearance of which leads to a decrease in the biological diversity of animal genetic resources and, most importantly, leads to loss of cultural heritage of the nation (Tisdell, 2003; Baranovs'kyy et al., 2005; Shuplyk et al., 2013; Stolpovskiy \& Zakharov-Gezekhus, 2017).

In this regard, native breeds are highly valued in the developed countries of the world as carriers of the gene pool and rare genetic complexes, providing the formation of economically useful features lost in highly intensive specialized modern breeds. 
Despite the complexity of the situation that has arisen, it is necessary for its elimination to take a set of actions to protect the Lebedyn breed, because its disappearance will lead to depletion of genetic diversity and restriction of breeding opportunities which can help in the improvement of newly created breeds. In this regard, scientists are faced with the task of making a comprehensive study of genetic resources, control of breeding situation and the development of methods for preserving the gene pool in a closed population.

Using the achievements of modern genetics in the breeding process is the basis for successful and effective work aimed at obtaining highquality and competitive products. At the present stage of the development of science, the use of DNA technology plays a significant role in the practice of world livestock breeding (Naqvi, 2007; Glazko, 2011; Khlestkina, 2013; Al-Samarai \& Al-Kazaz, 2015).

To solve a number of problems related to the scientific support of breeding work, in particular on the certification of animal breeds, determination of the level of consolidation of created groups and the degree of genetic differentiation of populations, a separate class of molecular genetic markers is widely used named microsatellites (Debrauwere et al., 1997; Senan et al., 2014). Due to the high level of polymorphism of microsatellite markers, which are displayed in larger, relatively classical biallel systems, number of alleles per locus, microsatellites can be used as a rather subtle and effective tool for studying genetic variability, which makes it possible to successfully solve a whole range of the abovementioned issues (Sulimova, 2004; Shel'ov, 2015; Mishra et al., 2017).

The aim of this work was to study the genetic structure of a Lebedyn cattle population using a set of 10 microsatellite markers, according to the recommendations of FAO-ISAG (ETH225, BM2113, ETH3, BM1818, BM1824, ILSTS006, INRA023, TGLA53, TGLA122, ETH10) (FAO, 2011).

\section{Material and methods}

The object of the study was a population of cattle of the Lebedyn breed in a private agricultural enterprise (PAE) "Komyshans'ke", Sumy region. The sample consisted of 30 individuals. DNA was extracted from hair bulbs using a commercial set of reagents "DNA-Sorb B" (AmpliSens, Russia).

According to recommendations of FAO-ISAG, for studies we selected 10 microsatellite loci: ETH225, BM2113, ETH3, BM1818, BM1824, ILSTS006, INRA023, TAGLA053, TAGLA12, ETH10 (Table 1). The amplification of fragments of the studied loci was carried out using a thermal cycler "Amply-4" ("Biocom", Russia) according to the appropriate program: 1 cycle - denaturation $94^{\circ} \mathrm{C}, 3 \mathrm{~min} ; 35$ cycles denaturation $94{ }^{\circ} \mathrm{C} 30 \mathrm{~s}$, annealing $30 \mathrm{~s}\left(56-62{ }^{\circ} \mathrm{C}\right.$ depending on the locus), elongation $72{ }^{\circ} \mathrm{C} 50 \mathrm{~s} ; 1$ cycle - final elongation $72{ }^{\circ} \mathrm{C} 10 \mathrm{~min}$. the volume of reaction mixture was $20 \mu \mathrm{L}$, the concentration of primers was $0.2 \mu \mathrm{m}$ in each case.

Amplification products were separated in polyacrylamide gels of different concentrations (5-8\%), both native and denaturing. Gel staining was carried out by using of ethidium bromide (visualization was carried out in the ultraviolet spectrum) or silver nitrate. The fragment size was determined using molecular weight markers pUC19 and ORange Ruler 20 bp (Thermo Scientific, USA).

Genotyping of individuals by a set of microsatellite markers in native polyacrylamide gels was carried out according to the authors' method (Kulibaba \& Liashenko, 2016). On the basis of the data obtained, the frequencies of genotypes and alleles, observed $\left(\mathrm{H}_{\mathrm{o}}\right)$ and expec ted $\left(\mathrm{H}_{\mathrm{e}}\right)$ heterozygosity, effective number of alleles $\left(\mathrm{n}_{\mathrm{e}}\right)$, Wright fixation index $\left(\mathrm{F}_{\text {is }}\right)$ were calculated, the test of distribution of genotypes in accordance to Hardy-Weinberg was conducted according to general methods (Merkur'eva, 1977; Kuznetsov, 2014).

Table 1

Nucleotide primer sequences for microsatellite loci

\begin{tabular}{|c|c|c|c|c|}
\hline No & Name & Primers (5'-3') & Annealing, ${ }^{\circ} \mathrm{C}$ & Amplicons, bp \\
\hline 1 & $\begin{array}{c}\text { ETH225 } \\
\text { (Chromosome 9) }\end{array}$ & $\begin{array}{l}\text { gatcaccttgccactatttcct; } \\
\text { acatgacagccagctgctact }\end{array}$ & 58 & 131-159 \\
\hline 2 & $\begin{array}{c}\text { BM2113 } \\
\text { (Chromosome 2) }\end{array}$ & $\begin{array}{l}\text { gctgccttctaccaaataccc; } \\
\text { cttcctgagagaagcaacacc }\end{array}$ & 58 & $122-156$ \\
\hline 3 & $\begin{array}{c}\text { ETH3 } \\
\text { (Chromosome 19) }\end{array}$ & $\begin{array}{l}\text { gaacctgcctctcctgcattgg; } \\
\text { actctgectgtggccaagtagg }\end{array}$ & 60 & 103-133 \\
\hline 4 & $\begin{array}{c}\text { BM1818 } \\
\text { (Chromosome 23) }\end{array}$ & $\begin{array}{l}\text { agctgggaatataaccaaagg; } \\
\text { agtgctttcaaggtccatgc }\end{array}$ & 58 & $248-278$ \\
\hline 5 & $\begin{array}{c}\text { BM1824 } \\
\text { (Chromosome 1) }\end{array}$ & $\begin{array}{l}\text { gagcaaggtgttttccaatc; } \\
\text { cattctccaactgcttccttg }\end{array}$ & 56 & 176-197 \\
\hline 6 & $\begin{array}{c}\text { ILSTS006 } \\
\text { (Chromosome 7) }\end{array}$ & $\begin{array}{l}\text { tgtctgtatttctgctgtgg; } \\
\text { acacggaagcgatctaaacg }\end{array}$ & 56 & 277-309 \\
\hline 7 & $\begin{array}{c}\text { INRA023 } \\
\text { (Chromosome 3) }\end{array}$ & $\begin{array}{l}\text { gagtagagctacaagataaacttc; } \\
\text { taactacagggtgttagatgaactc }\end{array}$ & 58 & $195-225$ \\
\hline 8 & $\begin{array}{c}\text { TGLA53 } \\
\text { (Chromosome 16) }\end{array}$ & $\begin{array}{l}\text { gcttcagaaatagtttgcattca; } \\
\text { atcttcacatgatattacagcaga }\end{array}$ & 58 & 143-191 \\
\hline 9 & $\begin{array}{c}\text { TGLA122 } \\
\text { (Chromosome 21) }\end{array}$ & $\begin{array}{l}\text { ccctcctccaggtaaatcagc; } \\
\text { aatcacatggcaaataagtacatac }\end{array}$ & 58 & $136-184$ \\
\hline 10 & $\begin{array}{c}\text { ETH10 } \\
\text { (Chromosome 5) }\end{array}$ & $\begin{array}{l}\text { gttcaggactggccctgctaaca; } \\
\text { cctccagcccactttcttttctc }\end{array}$ & 62 & $207-231$ \\
\hline
\end{tabular}

For estimation of selection (breeding) work that was carried out, the analysis of the ratio of observed values $\left(\mathrm{H}_{\mathrm{o}}\right)$ and the expected $\left(\mathrm{H}_{\mathrm{e}}\right)$ heterozygosity in a set of different polymorphic loci was used. In particular, if the differences between $\mathrm{H}_{\mathrm{o}}$ and $\mathrm{H}_{\mathrm{e}}$ are not expressed, that is, $\mathrm{H}_{\mathrm{o}}=\mathrm{H}_{\mathrm{e}}$, then there is an equilibrium state (panmixia), in which there is no breeding work in any direction affecting this locus. Under the conditions of $\mathrm{H}_{\mathrm{o}}<\mathrm{H}_{\mathrm{e}}$ in the population there is a pronounced deficiency of heterozygous individuals (in fact), which in turn indicates the presence of inbreeding (closely related crossing). Under the conditions of $\mathrm{H}_{0}>$ $\mathrm{H}_{\mathrm{e}}$, there is an excess of heterozygotes (an increase in the number of heterozygous individuals relative to calculated values), which, in turn, indicates outbreeding (Kuznetsov, 2014).

The study was conducted in the Laboratory of Molecular, Genetic, Physiological and Biochemical Researches in Livestock at the Institute of Animal Husbandry of NAAS.

\section{Results}

According to the results of the research, it was found that all microsatellite loci that were used in the experimental animal population are polymorphic. That proportion of polymorphic loci was $100 \%$.

The number of revealed alleles at the locus ranged from 4 to 8 . The analysis of the obtained results of genotyping allowed us to detect in total 51 alleles in 10 microsatellite loci (5 alleles at locus), whose size ranged from $115 \mathrm{bp}$ (ETH3) up to $307 \mathrm{bp}$ (ILSTS006) (Fig. 1). By the number of alleles, the most polymorphic were the loci TGLA53 (8 alleles), BM2113 (6), ETH3 (6); the smallest - loci BM1818 (4), BM1824 (4), ILSTS006 (4), TGLA122 (4) and ETH10 (4). The frequency of alleles for each of the studied loci has been determined. Data on the allele frequencies for each of the SSR-markers are presented in Table 2.

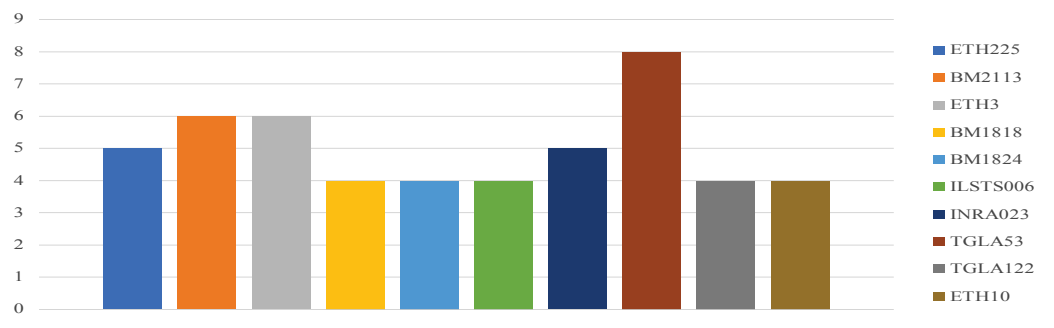

Fig. 1. The allele number ratio at the identified microsatellite loci in experimental populations 
Table 2

Values of allele frequencies of the revealed polymorphic loci

\begin{tabular}{|c|c|c|c|c|c|c|c|}
\hline Locus & Allele & Frequency & Error & Locus & Allele & Frequency & Error \\
\hline \multirow{5}{*}{ ETH225 } & 140 & 0.467 & $0.064 * * *$ & \multirow{4}{*}{ ILSTS006 } & 291 & 0.233 & $0.055^{* * *}$ \\
\hline & 146 & 0.150 & $0.046^{*}$ & & 295 & 0.183 & $0.050^{* * *}$ \\
\hline & 150 & 0.050 & $0.028^{\mathrm{ns}}$ & & 301 & 0.200 & $0.052 * * *$ \\
\hline & 152 & 0.133 & $0.044^{* *}$ & & 307 & 0.383 & $0.063 * * *$ \\
\hline & 154 & 0.200 & $0.052 * *$ & \multirow{5}{*}{ INRA023 } & 199 & 0.017 & $0.017^{\mathrm{ns}}$ \\
\hline \multirow{6}{*}{ BM2113 } & 125 & 0.183 & $0.050^{* * *}$ & & 203 & 0.067 & $0.032 *$ \\
\hline & 127 & 0.267 & $0.057 * * *$ & & 211 & 0.550 & $0.064^{* * *}$ \\
\hline & 135 & 0.067 & $0.032 *$ & & 215 & 0.050 & $0.028^{\mathrm{ns}}$ \\
\hline & \multirow{2}{*}{$\begin{array}{l}137 \\
139\end{array}$} & \multirow{2}{*}{$\begin{array}{l}0.133 \\
0200\end{array}$} & $0.044^{* *}$ & & 219 & 0.317 & $0.060 * * *$ \\
\hline & & & $0.052 * * *$ & \multirow{8}{*}{ TGLA053 } & 160 & 0.017 & $0.017^{\mathrm{ns}}$ \\
\hline & 141 & 0.150 & $0.046^{* *}$ & & 168 & 0.067 & $0.032 *$ \\
\hline \multirow{6}{*}{ ETH3 } & 115 & 0.617 & $0.063 * * *$ & & 170 & 0.500 & $0.065^{* * *}$ \\
\hline & 117 & 0.017 & $0.017^{\mathrm{ns}}$ & & 174 & 0.067 & $0.032 *$ \\
\hline & 119 & 0.033 & $0.023^{\mathrm{ns}}$ & & 178 & 0.067 & $0.032 *$ \\
\hline & 121 & 0.033 & $0.023^{\mathrm{ns}}$ & & 180 & 0.183 & 0.050 **** \\
\hline & 125 & 0.017 & $0.017^{\mathrm{ns}}$ & & 182 & 0.033 & $0.023^{\mathrm{ns}}$ \\
\hline & 127 & 0.283 & $0.058^{* * *}$ & & 190 & 0.067 & $0.032 *$ \\
\hline \multirow{4}{*}{ BM1818 } & 266 & 0.300 & 0.059 *** & \multirow{5}{*}{ TGLA122 } & 148 & 0.133 & $0.044 * *$ \\
\hline & 268 & 0.133 & $0.044^{* *}$ & & 152 & 0.333 & $0.061^{* * *}$ \\
\hline & 276 & 0.550 & $0.064^{* * *}$ & & 156 & 0.017 & $0.017^{\mathrm{ns}}$ \\
\hline & 278 & 0.017 & $0.017^{\mathrm{ns}}$ & & 160 & 0.417 & $0.064^{* * *}$ \\
\hline \multirow{5}{*}{ BM1824 } & 190 & 0.350 & $0.062 * * *$ & & 172 & 0.100 & $0.039^{*}$ \\
\hline & 192 & 0.050 & $0.028^{\mathrm{ns}}$ & \multirow{4}{*}{ ETH10 } & 216 & 0.133 & $0.044 * *$ \\
\hline & 194 & 0.233 & $0.055^{* * *}$ & & 218 & 0.250 & $0.056^{* * *}$ \\
\hline & \multirow{2}{*}{196} & \multirow{2}{*}{0.367} & \multirow{2}{*}{$0.062 * * *$} & & 222 & 0.150 & $0.046^{* *}$ \\
\hline & & & & & 224 & 0.467 & $0.064^{* * *}$ \\
\hline
\end{tabular}

Notes: *- $\mathrm{P}<0.05 ;{ }^{* *}-\mathrm{P}<0.01$; *** $-\mathrm{P}<0.001{ }^{\text {ns }}-$ not significant.

By the number of revealed genotypes, the studied microsatellite loci differed significantly from each other. So for TGLA53, only 15 out of 32 possible genotypes were detected. In this case, the frequency of occurrence of two (genotypes) was $50 \%$, and 11 genotypes were found only 1 time (less than 5\%). Such distribution of genotypes influenced the effective number of alleles, which was 3.3 out of 8 (Table 3). Among the 6-allele loci, the BM2113 was more balanced at allele frequencies $(0.17 \pm 0.03)$ and the maximum value of the effective number of alleles among the studied loci $\left(\mathrm{n}_{\mathrm{e}}=5.3\right)$.

ETH3 locus, by contrast, was represented by only 7 of the 21 possible genotypes with a frequency shifted towards two of them $(75 \%$ of the total), which affected the value of ne (2.16 - the lowest value among all studied loci). 5 alleles were identified for 3 microsatellite loci ETH225, INRA023 and TGLA122. The distribution of allele frequencies within these loci was characterized by the maximum manifestation of one of them (0.42-0.55) and the presence of 2-3 minor alleles $(0.02$ 0.06). The remaining loci (BM1818, BM1824, ILSTS006 and ETH10) are represented by 4 alleles. The greatest contribution to allelic diversity was made by allele frequencies for locus ILSTS006 (ne=3.64), the least $-\mathrm{BM} 1818\left(\mathrm{n}_{\mathrm{e}}=2.44\right)$.

Table 3 presents the main parameters of genetic variability of the experimental population of animals by the revealed polymorphic loci. Another important indicator of the genetic variability of populations is the evaluation of its heterozygosity. Among the two indexes of heterozygosity, $\mathrm{H}_{\mathrm{o}}$ and $\mathrm{H}_{\mathrm{e}}$, only the latter points to the level of polymorphism of a population. The maximum value of expected heterozygosity $\left(\mathrm{H}_{\mathrm{e}}\right)$ was noted for BM2113 (0.81), ILSTS006 (0.73), TGLA053 (0.70) and ETH225 (0.70) loci. The rest of the loci were characterized by an average level of investigated parameter $(0.54-0.69)$ (Fig. 2).

The value of observed heterozygosity index and its ratio with the expected $\left(\mathrm{F}_{\mathrm{is}}\right)$ indicate the changes occurring in the population under the influence of microevolution processes (selection, drift of genes, etc.). The analysis of the data showed that an equilibrium state between the observed and expected indexes is peculiar to the majority of microsatellite loci. The criterion for such assessment is the verification of the distribution of genotypes by Hardy-Weinberg using the $\chi^{2}$ method. Thus, only in 2 out of 10 cases, was there a significant deviation in the form of excess heterozygote for ETH3 locus (5.6\%) and their deficiency for VM1818 (37.8\%). The average value of Wright's fixation index gives reason to believe that there is a tendency to increase the number of homozygous individuals in the study population (inbreeding within $6.5 \pm 5.1 \%$ ).

Table 3

The main genetic and population characteristics of the experimental animal population

\begin{tabular}{lccccrcc}
\hline \multirow{2}{*}{ Locus } & \multicolumn{7}{c}{ Parameters } \\
\cline { 2 - 8 } & $\mathrm{N}_{\mathrm{a}}$ & $\mathrm{n}_{\mathrm{e}}$ & $\mathrm{H}_{\mathrm{o}}$ & $\mathrm{H}_{\mathrm{e}}$ & \multicolumn{1}{c}{$\mathrm{F}_{\mathrm{is}}$} & $\chi^{2}$ & Significance \\
\hline ETH225 & 5 & 3.327 & 0.600 & 0.699 & 0.142 & 11.218 & $\mathrm{~ns}$ \\
BM2113 & 6 & 5.279 & 0.833 & 0.811 & -0.028 & 17.084 & $\mathrm{~ns}$ \\
ETH3 & 6 & 2.158 & 0.567 & 0.537 & -0.056 & 33.034 & $* *$ \\
BM1818 & 4 & 2.436 & 0.367 & 0.589 & 0.378 & 14.973 & $*$ \\
BM1824 & 4 & 3.186 & 0.633 & 0.686 & 0.077 & 7.745 & $\mathrm{~ns}$ \\
ILSTS006 & 4 & 3.636 & 0.700 & 0.725 & 0.034 & 6.393 & $\mathrm{~ns}$ \\
INRA023 & 5 & 2.439 & 0.667 & 0.590 & -0.130 & 13.433 & $\mathrm{~ns}$ \\
TGLA53 & 8 & 3.303 & 0.567 & 0.697 & 0.187 & 34.905 & $\mathrm{~ns}$ \\
TGLA122 & 5 & 3.197 & 0.567 & 0.687 & 0.175 & 8.482 & $\mathrm{~ns}$ \\
ETH10 & 4 & 3.120 & 0.767 & 0.679 & -0.128 & 7.734 & $\mathrm{~ns}$ \\
Average & 5.100 & 3.208 & 0.627 & 0.670 & 0.065 & - & - \\
$\quad$ Error & 0.407 & 0.275 & 0.041 & 0.025 & 0.051 & - & - \\
\hline
\end{tabular}

Notes: $\mathrm{N}_{\mathrm{a}}-$ number of alleles; $\mathrm{n}_{\mathrm{e}}-$ effective number of alleles; $\mathrm{H}_{\mathrm{o}}-$ observed heterozygosity; $\mathrm{H}_{\mathrm{e}}$ - expected heterozygosity; $\mathrm{F}_{\mathrm{is}}-$ Wright's fixation index; $\chi^{2}-$ xi-square criterion; ${ }^{\text {ns }}-$ not significant.

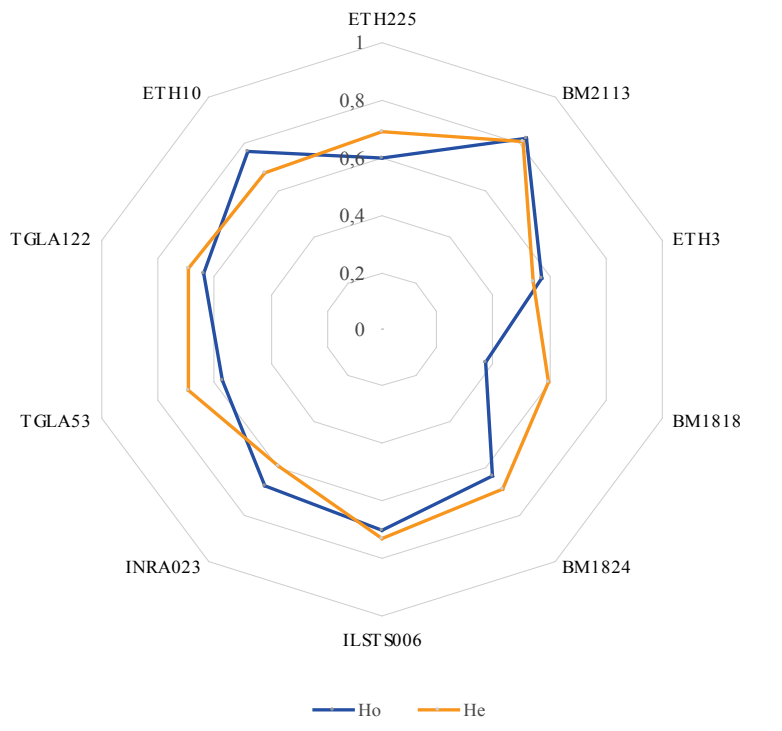

Fig. 2. Expected $\left(\mathrm{H}_{\mathrm{e}}\right)$ and observed $\left(\mathrm{H}_{\mathrm{o}}\right)$ heterozygosity in the experimental population of animals

\section{Discussion}

The received data about genetic structure of population of cattle based on complex microsatellite loci are a valuable source of information in terms of the conservation of the gene pool of the breed. The level of microsatellite allelic diversity as selection-neutral molecular markers is used to monitor genetic processes in artificially reproduced animal populations. It is especially important for minority breeds that are endangered.

According to the register of subjects of the breeding business in livestock farming, today there is one breeding plant (PJSC "Mykhaylivka" of Sumy region) and two pedigree reproducers (PAE "Komyshans'ke" in Sumy region and LLC "Mriya" of Chernihiv region) in the structure of support for the Lebedyn breed (Derzhavnyy reyestr, 2018). According to data for 2017, the total number of animals was 1,550 head (including 640 cows: 110, 293 and 237, respectively) (Derzhavnyy reyestr, 2013). In the past 6 years, the number of livestock of this breed has decreased by 1.8 times (from 2,740 to 1,550 ) and is approaching a critical threshold for which recovery may become impossible. The risk of loss of genetic diversity and allelic combinations that are valuable for the breed, is dramatically increasing in small populations under the influence of factors of selection, genetic drift and migration. 
Taking into account the potential value of local aboriginal breeds as carriers of specific biological and economic features for specific geoclimatic conditions of breeding, it would be advisable to analyze changes in the genetic structure of experimental populations of cows by microsatellite markers compared with the data of previous years of research, with data of the initial forms involved in the creation of the breed. Unfortunately, in accessible literary sources, there was not enough information about the subject of research that could be correctly used for analysis. In the majority of publications there was no data about allele frequencies, generally the authors results gave average values of genetic-population indicators, making it impossible to use these data by other researchers in case of deviations in the set of molecular markers (Shel'ov et al., 2017, Guseev et al., 2016). For analysis, we were able to select only a few articles, containing information directly on the Lebedyn breed (data for 2015, PJSC "Mykhaylivka" (Shkavro et al., 2018), and for 4 breeds which could be related to it to some extent (which have a common origin): Ukrainian grey (DPDH "Polyvanivkas, $\mathrm{n}=27$ (Shkavro et al., 2010)), Bulgarian grey (Sredets, Bulgaria, $\mathrm{n}=35$ (Teneva et al., 2005)), Red steppe (DTPP "Stepne", $\mathrm{n}=35$ (Kramarenko et al., 2018)), Swiss and Simmental (Switzerland, $n=44$ (Schmid et al., 1999)).

Table 4 presents data on the number of alleles per microsatellite locus, which give a general idea of the polymorphism level of the studied breeds. On average, Ukrainian grey had the smallest number of alleles (4.6) and Bulgarian grey had the largest (7.2). The populations of cattle of the Lebedyn breed which were kept in different farms of Sumy region had a similar level of allelic polymorphism (5.4-5.7).

Table 4

The number of alleles by microsatellite loci of 7 breeds of cattle

\begin{tabular}{|c|c|c|c|c|c|c|c|}
\hline Locus & $\begin{array}{l}\text { Lebedyn } \\
\text { («Komy- } \\
\text { shans'ke») }\end{array}$ & $\begin{array}{c}\text { Lebedyn } \\
\text { («Mykhay- } \\
\text { livka») }\end{array}$ & $\begin{array}{c}\text { Red } \\
\text { steppe }\end{array}$ & $\begin{array}{c}\text { Ukrainian } \\
\text { grey }\end{array}$ & $\begin{array}{l}\text { Bulgarian } \\
\text { grey }\end{array}$ & Swiss & Simmental \\
\hline TH225 & 5 & 6 & - & 6 & 6 & 6 & 6 \\
\hline M2113 & 6 & 7 & 7 & 4 & 7 & 8 & 7 \\
\hline ETH3 & 6 & 4 & 8 & 4 & 9 & 4 & 6 \\
\hline BM1824 & 4 & 4 & 4 & 4 & 4 & 5 & 4 \\
\hline INRA023 & 5 & 3 & 4 & 6 & 6 & 7 & 7 \\
\hline TGLA53 & 8 & 10 & 6 & 5 & 12 & 10 & 10 \\
\hline ETH10 & 4 & 4 & 7 & 3 & 5 & 4 & 3 \\
\hline TGLA122 & 5 & 8 & 6 & - & 9 & 9 & 8 \\
\hline Average & 5.38 & 5.75 & 6.00 & 4.57 & 7.25 & 6.63 & 6.38 \\
\hline Error & 0.460 & 0.860 & 0.540 & 0.401 & 0.920 & 0.800 & 0.777 \\
\hline
\end{tabular}

In order to objectively assess the level of genetic polymorphism, in addition to the number of alleles, it was necessary to conduct the analysis of their frequencies. These are genetic-population parameters such as the expected heterozygosity $\left(\mathrm{N}_{\mathrm{e}}\right)$, the effective number of alleles $\left(\mathrm{n}_{\mathrm{e}}\right)$, the index of information polymorphism (PIC) (Table 5). Almost all investigated loci can be attributed to informatively valuable markers (PIC > 0.5). Only two loci were exceptions - ETN3 (Lebedyn (Komyshans'ke), 0.47; Ukrainian grey, 0.49) and VM1818 (Lebedyn (Mykhaylivka), 0,46).

Table 5

Basic parameters of genetic variability of different cattle breeds by microsatellite loci

\begin{tabular}{lccccc}
\hline Parameter & $\begin{array}{c}\text { Lebedyn } \\
\text { (Komyshans'ke) }\end{array}$ & $\begin{array}{c}\text { Lebedyn } \\
\text { (Mykhaylivka) }\end{array}$ & $\begin{array}{c}\text { Red } \\
\text { steppe }\end{array}$ & $\begin{array}{c}\text { Ukrainian } \\
\text { grey }\end{array}$ & $\begin{array}{c}\text { Bulgarian } \\
\text { grey }\end{array}$ \\
\hline $\mathrm{H}_{\mathrm{e}}$ & 0.667 & 0.706 & 0.686 & 0.643 & 0.878 \\
Error $_{\mathrm{e}}$ & 0.039 & 0.044 & 0.052 & 0.036 & 0.034 \\
$\mathrm{~N}_{\mathrm{e}}$ & 3.248 & 3.815 & 3.570 & 2.978 & 4.61 \\
Error $\mathrm{N}_{\mathrm{e}}$ & 0.447 & 0.600 & 0.486 & 0.348 & 0.465 \\
PIC & 0.617 & 0.664 & 0.649 & 0.588 & 0.742 \\
Error PIC & 0.045 & 0.049 & 0.054 & 0.039 & 0.030 \\
\hline
\end{tabular}

The most common measure of genetic diversity of the population is the He (Khedrik, 2003) index. The distribution of heterozygosity indices in the studied cattle breeds by the aggregate of loci reflects the direct dependence on the total number of alleles (not always the case) - the breeds, for which a relatively low index of $\mathrm{N}_{\mathrm{a}}$ was determined, were also characterized by lower values of $\mathrm{He}(0.64 \pm 0.04$ and $0.67 \pm 0.04$ for the Ukrainian grey and Lebedyn breeds (Komyshans'ke), respecti- vely). Another indicator of genetic diversity correlated with the number of alleles and heterozygosity, and also reflecting the alignment of allele frequencies is ne. The most promising in terms of maintaining of genetic variability is the situation in the experimental population of the Bulgarian grey breed $\left(n_{e}=4.6\right.$ out of 7.2 alleles). The smallest number of effective alleles was found in the experimental populations of the Ukrainian grey and Lebedyn breeds (Komyshans'ke) - 3.0 and 3.2, respectively. In addition, the proportion of effective alleles of the Komyshans'ke population was the lowest and amounted to 59\% (3.2 alleles out of 5.5)

The given analysis of genetic-population parameters confirmed the negative effect of reducing the number of livestock on the genetic diversity of local breeds of cattle. The worst results were obtained for populations of the Ukrainian grey and Lebedyn breeds, the total number of which at the time of taking samples was 607-738 head (of which 266293 cows). The situation was somewhat better in the experimental herd of the Red steppe breed, the number of which in Ukraine is higher in comparison with Ukrainian grey and Lebedyn (4,094 against 954 (Grey) and 1,550 (Lebedyn)). The Grey Bulgarian breed (information about livestock not available) is one of the oldest aboriginal breeds in Bulgaria and represents value as a gene pool object. Analysis of the genetic processes that occurred during reproduction of the experimental herd of this breed indicates a sufficient supply of genetic variability and the adequacy of schemes used in selection and breeding work.

\section{Conclusions}

The genetic structure of the experimental population of cattle of the Lebedyn breed was analyzed for 10 microsatellite loci (ETH225, BM2113, ETH3, BM1818, BM1824, ILSTS006, INRA023, TGLA053, TGLA122, ETH10). The vast majority of investigated loci (except ETH3) belonged to informatively valuable markers (PIC $>0.5$ ). The most polymorphic loci were TGLA053 (8 alleles), BM2113 (6) and ETH3 (6). In general, the minimum number of alleles (4) was recorded in $50 \%$ of the loci. The main population-genetic parameters by the studied loci were calculated. The highest values of heterozygosity $\left(\mathrm{H}_{\mathrm{e}}\right)$ and effective number of alleles $\left(\mathrm{n}_{\mathrm{e}}\right)$ were characteristic of BM2113, ILSTS006, TGLA053 and ETH225 loci. With the exception of the ETH3 and VM1818 loci, the experimental group of animals was in a state of genetic equilibrium. The average value of the Wright's fixation index gives evidence of a tendency to increase in the number of homozygous individuals (inbreeding). Comparative analysis of the genetic structure of breeds that have a common origin gives reason to believe that the experimental population of Lebedyn cattle is subject to processes that lead to a reduction of genetic diversity. In order to overcome the negative effects of artificial reproduction in the gene pool of small populations of cattle, which include Lebedyn cattle, it is appropriate to use microsatellite markers in the selection and breeding work.

\section{References}

Al-Samarai, F. R., \& Al-Kazaz, A. A. (2015). Molecular markers and its applications in animal breeding: A review. American Journal of Applied Scientific Research, 1(1), 1-5.

Baranovs'kyy, D. I., Herasymov, V. I., \& Nahayevych, V. M. (2005). Henofond sviys'kykh tvaryn Ukrayiny [The gene pool of domestic animals of Ukraine]. Espada, Kharkiv (in Ukrainian).

Basovs'kyy, D. M. (2013). Problemy zberezhennya henofondu lebedyns'koyi porody [Problems of preserving the gene pool of Lebedyn cattle]. Rozvedennya i henetyka tvaryn. Animal Breeding and Genetics, 47, 145-151 (in Ukrainian).

Debrauwere, H., Gendrel, C. G., Lechat, S., \& Dutreix, M. (1997). Differences and similarities various tandem repeat sequences: Minisatellites and microsatellites. Biochimie, 79, 577-586.

FAO (2011). Molecular genetic characterization of animal genetic resources. FAO animal production and health guidelines. No. 9. Rome, Italy.

Glazko, V. I. (2011). Genomnaya selektsiya krupnogo rogatogo skota: issledovatel'skie i prikladnye zadachi [Genomic selection of cattle: Research and applied tasks]. Izvestiya TSKhA, 5, 126-135 (in Russian).

Guseev, Y. V., Mtlyyk, O. V., Gladyr, E. A., \& Zinovieva, N. A. (2016). The polymorphism of five microsatellite DNA loci in the study of grey Ukrainian and Bulgarian grey cattle breeds. Animal Breeding and Genetics, 52, 202-211. 
Hladiy, M. V., Polupan, Y. P., Basovs'kyy, D. M., \& Vyshnevs'kyy, L. V. (2018). Prohrama zberezhennya henofondu lokal'nykh i znykayuchykh porid sil's'kohospodars'kykh tvaryn v Ukrayini na 2017-2025 [Program for preserving the gene pool of local and endangered breeds of farm animals in Ukraine for 2017-2025]. Sumy (in Ukrainian).

Khedrik, F. (2003). Genetika populyatsiy [Genetics of populations]. Tekhnosfera, Moscow (in Russian)

Khlestkina, E. K. (2014). Molecular markers in genetic studies and breeding. Russian Journal of Genetics: Applied Research, 4(3), 236-244.

Kramarenko, A. S., Gladyr, E. A., Kramarenko, S. S., Pidpala, T. V., Strikha, L. A., \& Zinovieva, N. A. (2018). Genetic diversity and bottleneck analysis of the Red Steppe cattle based on microsatellite markers. Ukrainian Journal of Ecology, 8(2), 12-17.

Kulibaba, R. A., \& Liashenko, Y. V. (2016). Influence of the PCR artifacts on the genotyping efficiency by the microsatellite loci using native polyacrylamide gel electrophoresis. Cytology and Genetics, 50(3), 162-167.

Kuznetsov, V. M. (2014). F-statistiki Rayta: Otsenka i interpretatsiya [Wright's Fstatistics: Evaluation and interpretation). Problems of Biology of Productive Animals, 4, 80-104 (in Russian).

Merkur'eva, E. K. (1977). Geneticheskie osnovy selektsii v skotovodstve [Genetic principles of selective breeding in cattle breeding]. Kolos, Moscow (in Russian).

Mishra, S. P., Mishra, C., Mishra, D. P., Rosalin, B. P., \& Bhuyan, C. (2017). Application of advanced molecular marker technique for improvement of animal: A critical review. Journal of Entomology and Zoology Studies, 5(5), $1283-1295$.

Naqvi, A. N. (2007). Application of molecular genetic technologies in livestock production: Potentials for developing countries. Advances in Biological Research, 1(3-4), 72-84.

Prokhorenko, P. (2013). Golshtinskaya poroda i ee vliyanie na geneticheskiy progress produktivnosti cherno-pestrogo skota evropeyskikh stran i rossiyskoy federatsii [Holstein breed and its influence on the genetic progress of the productivity of Black-and-White cattle in European countries and the Russian Federation]. Molochnoe i Myasnoe Skotovodstvo, 2, 2-6 (in Russian).

Schmid, M., Saitbekova, N., Gaillard, C., \& Dolf, G. (1999). Genetic diversity in Swiss cattle breeds. Journal of Animal Breeding and Genetics, 116, 1-8.

Senan, S., Kizhakayil, D., Sasikumar, B., \& Sheeja, T. E. (2014). Methods for development of microsatellite markers: An overview. Notulae Scientia Biologicae, 6(1), 1-13.
Shel'ov, A. V. (2015). Polimorfizm mikrosatelitnykh lokusiv DNK u riznykh vydiv sil's'kohospodars'kykh tvaryn [Polymorphism of microsatellite DNA loci in different species of farm animals]. Animal Breeding and Genetics, 50, 183-190 (in Ukrainian).

Shel'ov, A. V., Kopylov, K. V., Kramarenko, S. S., \& Kramarenko, O. S. (2017). Analysis of population-genetic processes in different cattle breeds by microsatellite loci of DNA. Agricultural Science and Practice, 4(1), 74-78.

Shkavro, N. M., Radko, A., Slota, E., \& Rossokha, V. I. (2010). Polimorfizm mikrosatelitnykh markeriv DNK dvokh porid velykoyi rohatoyi khudoby [Polymorphism of microsatellite DNA markers two breeds of cattle]. Visnyk Kharkivs'koho Natsional'noho Universytetu imeni V. N. Karazina. Seriya Biolohiya, 905(11), 120-126 (in Ukrainian).

Shkavro, N., Blyzniuk, O., Pomitun, I., \& Babicz, M. (2018). Evaluation of the genetic structure and main productive traits of Lebedyn cattle based on genetic markers polymorphism. Journal of Animal Science Biology and Bioeconomy, 36(2), 17-26.

Shuplyk, V. V., Savchuk, O. V., \& Huzyev, I. V. (2013). Henofond porid sil's'kohospodars'kykh tvaryn Ukrayiny [Genetic pool of breeds of farm animals in Ukraine]. Vydavets' PP Zvoleyko D. H., Kam'yanets'-Podil's'kyy (in Ukrainian).

Sirats'kyy, Y. Z. (Ed.). (2001). Bura khudoba v Ukrayini [Brown Cattle in Ukraine]. Naukovyy Svit, Kyiv (in Ukrainian).

Stolpovskiy, Y. A., \& Zakharov-Gezekhus, I. A. (2017). Problema sokhraneniya genofondov domestitsirovannykh zhivotnykh [The problem of preserving the gene pools of domesticated animals]. Vavilov Bulletin of Genetics and Breeding, 21(4), 477-486 (in Ukrainian).

Sulimova, G. E. (2004). DNK-markery v geneticheskikh issledovaniyakh: Tipy markerov, ikh svoystva i oblasti primeneniya [DNA markers in genetic studies: Types of markers, their properties and areas of application]. Successes of Modern Biology, 124, 260-271 (in Russian).

Teneva, A., Todorovska, E., Tyufekchiev, N., Atanassov, A., Foteva, S., Ralcheva, S., \& Zlatarev, S. (2005). Molecular characterization of Bulgarian livestock genetic resources [Genetic diversity in Bulgarian grey cattle as revealed by microsatellite markers]. Biotechnology in Animal Husbandry, 21(5-6), 35-41.

Tisdell, C. (2003). Socioeconomic causes of loss of animal genetic diversity: Analysis and assessment. Ecological Economics, 45(3), 365-376.

Yatsenko, A. E. (1997). Lebedinskaya poroda krupnogo rogatogo skota [Lebedyn breed of cattle]. BMT, Kyiv (in Russian). 